\title{
Influence of normal human serum on the determination of trichomonicidal drug concentrations
}

\author{
ARNE FORSGREN \\ Institute of Medical Microbiology, University of Uppsala, Uppsala, Sweden
}

Agglutinating and complement-fixing antibodies to Trichomonas vaginalis have been found in sera from infected patients of both sexes and also in control sera (Trussell and Wilson, 1942; Tatsuki, 1957). Weld and Kean (1958) described a cytolytic factor in human serum capable of destroying $T$. vaginalis in a few minutes. This factor was inactivated by heating for 30 min. at $56^{\circ} \mathrm{C}$. and lost activity on storage. All the human sera examined, as well as sera from rabbits, hamsters, guinea-pigs, rats, and dogs, were deleterious to $T$. vaginalis. This paper confirms the above report on the cytolytic factor. The influence of serum on determinations of the concentration of trichomonicidal drugs in serum has been investigated.

\section{Material and methods \\ STRAINS \\ Ten Trichomonas vaginalis strains isolated from clinical material and a reference strain, $T$. vaginalis Milan, kindly supplied by Dr. I de Carneri, were used.}

\section{CULTIVATION TECHNIQUE}

The trichomonicidal effects of metronidazole, nitrimidazine, and serum were tested, using doubling dilutions in serum, saline, or thioglycolate medium in a volume of $1 \mathrm{ml}$. per test-tube. $1 \mathrm{ml}$. of a suspension in thioglycolate medium of $8 \times 10^{4} \mathrm{~T}$. vaginalis organisms per ml. was added to each of the test-tubes, giving a final concentration of $4 \times 10^{4}$ viable organisms per ml. After 3 days' incubation at $37^{\circ} \mathrm{C}$., $0.2 \mathrm{ml}$. from each test-tube was transferred to $4 \mathrm{ml}$. Diamond's medium (Diamond, 1957) and the subculture was incubated for 5 days. Evaluation of trichomonicidal activity was based on the final result of subculture.

\section{Results}

As shown in the Table, all concentrations of nitrimidazine were completely trichomonicidal in fresh human serum diluted $1 / 2,1 / 4$, and $1 / 8$, when incubated with Trichomonas vaginalis, strain Milan, in a concentration of 40,000 organisms $/ \mathrm{ml}$. for 3 days. No viable Trichomonas vaginalis could be detected by subculture in Diamond's medium. However, low concentrations of nitrimidazine in serum diluted $1 / 16$ permitted the organisms to survive. When nitrimidazine was dissolved in serum diluted $1 / 32$ or more, Trichomonas vaginalis survived in the same concentrations of nitrimidazine as when the drug was dissolved in saline or thioglycolate medium. The lowest trichomonicidal concentration of nitrimidazine in serum inactivated for $30 \mathrm{~min}$. at $56^{\circ} \mathrm{C}$. was the same as for nitrimidazine in saline or in serum diluted $1 / 32$ or more.

TABLE

\begin{tabular}{|c|c|c|c|c|c|c|}
\hline \multirow{2}{*}{$\begin{array}{l}\text { Nitrimidazine } \\
\text { dissolved in }\end{array}$} & \multicolumn{6}{|c|}{ Concentration of nitrimidazine ( $\mu \mathrm{g} . / \mathrm{ml}$. ) } \\
\hline & $2 \cdot 5$ & $1 \cdot 25$ & 0.6 & 0.3 & $0 \cdot 15$ & 0.08 \\
\hline \multicolumn{7}{|l|}{ Human serum } \\
\hline $1: 2$ & - & - & - & - & - & - \\
\hline $1: 4$ & - & - & - & - & - & - \\
\hline $1: 8$ & - & - & - & - & - & - \\
\hline $1: 16$ & - & - & - & - & + & + \\
\hline $1: 32$ & - & - & - & + & + & + \\
\hline $1: 64$ & - & - & - & + & + & + \\
\hline $1: 128$ & - & - & - & + & + & + \\
\hline $1: 256$ & - & - & - & + & + & + \\
\hline Inactivated & & & & & & \\
\hline$\left(36^{\circ} \mathrm{C} ., 30 \mathrm{~min}.\right)$ & - & - & - & + & + & + \\
\hline Saline & - & - & - & + & + & + \\
\hline Thioglycolate medium & - & - & - & + & + & + \\
\hline
\end{tabular}

Trichomonas vaginalis, Milan, incubated for 3 days in a series of concentrations of nitrimidazine, each present in a series of dilutions of human serum. (-) indicates a trichomonicidal effect; no living organisms could be detected by subculture. $(+)$ indicates that living organisms were detected by subculture.

Reduced and varying trichomonicidal effects were obtained when serum that had been stored for some days at $+4^{\circ} \mathrm{C}$. or $-20^{\circ} \mathrm{C}$. or serum that had been frozen and thawed several times was used.

Results similar to those shown in the table were obtained when the sensitivity of Trichomonas vaginalis to metronidazole in serum was tested. Of the strains investigated, Trichomonas vaginalis Milan was the most sensitive to the effect of human serum. Different strains of Trichomonas vaginalis isolated in the routine laboratory showed different sensitivities to human serum. For three of our ten strains, fresh human serum diluted $1 / 2$ had no detectable trichomonicidal effect with the method used. 


\section{Discussion}

The chemotherapy of Trichomonas was significantly improved by the discovery of metronidazole (Cosar, Julou, and Bénazet, 1959). Nitrimidazine has been stated to have in vitro activity of the same order as that of metronidazole (de Carneri, 1969). The absorption of metronidazole and nitrimidazine after oral administration has been investigated by polarography (Kane, McFadzean, Squires, King, and Nicol, 1961) and gas-chromatography (Giraldi, Tosolini, Dradi, Nannini, Longo, Meinardi, Monti, and de Carneri, 1971). However, reports on serum levels of metronidazole (Jennison, Stenton, and Watt, 1961) and nitrimidazine (de Carneri, 1969), as determined by a biological method, have been presented. By that method, serum containing the drug under investigation is diluted and then inoculated with a strain of Trichomonas vaginalis.

The experiments presented in this paper show that fresh normal human serum in dilutions up to $1 / 8$ has a trichomonicidal effect under the conditions used for determination of the serum level of trichomonicidal drugs. The consequence of this is that, when the serum level of metronidazole or nitrimidazine is low or moderate and the serum is diluted $1 / 16$ or less, the trichomonicidal effect of the serum may be confused with that of the drugs, when biological determinations of drug concentrations in serum are performed, so that falsely high results can be obtained. The experiments also show that this can be avoided by inactivating the serum at $56^{\circ} \mathrm{C}$. for 30 minutes. The clinical importance of the differences in sensitivity to human serum among Trichomonas strains reported in this paper is unknown.

\section{Summary}

Fresh normal human serum has a trichomonicidal effect which can interfere with biological determinations of serum levels of metronidazole and nitrimidazine. When investigating heat-stable trichomonicidal drugs this can be avoided by inactivating the serum at $56^{\circ} \mathrm{C}$. for 30 minutes. Trichomonas strains were found to differ in their sensitivity to serum.

\section{References}

CARNERI, I. DE (1969) Arztneimittel-Forsch., 19, 382

Cosar, C., Julou, L., and Bénazet, M. (1959) Ann. Inst. Pasteur, 96, 238

Diamond, L. S. (1957) F. Parasitol., 43, 488

Giraldi, P. N., Tosolini, G. P., Dradi, E., Nannini, G., Longo, R., Meinardi, G., R. Monti, G., and Carneri, I. De (1971) Biochem. Pharmacol., 20, 339

Jennison, R. F., Stenton, P., and Watt, L. (1961) $\mathcal{F}$. clin. Path., 14, 431

Kane, P. O., McFadzean, J. A., SQuires, S., King, A. J., and NICoL, C. S. (1961) Brit. F. vener. Dis., 37, 273

TATsUKI, T. (1957) Nagasaki med. F., 32, 983

Trussell, R. E., and Wilson, M. E. (1942) Amer. $\mathcal{F}$. Obstet. Gynec., 44, 292

Weld, J. T., and Kean, B. H. (1958) Proc. Soc. exp. Biol. (N.Y.), 98, 494

\section{L'influence de sérum humain normal dans l'étude des médicaments trichomonacides \\ SOMMAIRE}

Le sérum humain frais normal a une action trichomonacide qui peut intervenir dans la détermination biologique des taux sériques de métronidazole et de nitrimidazine. Lorsque l'on étudie des médicaments dont l'action trichomonacide est thermostable, cet inconvénient peut être évité en inactivant le sérum à $56^{\circ} \mathrm{C}$. pendant 20 minutes. Les souches de trichomonas ont manifesté des différentes sensibilités vis-à-vis du sérum. 
unusual. The authors prefer benzyl benzoate to other treatments but insist that all members of the family and all sexual contacts should be treated even in the absence of overt lesions. Factors which encourage the spread of scabies are mass movements of population, depression and promiscuity. It is thought that pruritus and papulovesicular lesions are due to allergic hypersensitivity as the small number of mites does not account for the extent of lesions seen. Postscabietic pruritus and eosinophilia also support this view. One explanation for the present spread of scabies might be due to the previous low degree of infestation and absence of an immune response. This would fit in with the present spread of the infestation in children. Infestation does not lead to true immunity but is thought to produce a reactivity of the body giving rise to early symptoms when infected. G. W. Csonka

Torsion of the Testis and Its Appendages CHAPMAN, R. H., and WALTON, A. J. (1972) Brit. med. F., 1,16415 refs

\section{Prophylatic Treatment with Penicillin in Venereal Diseases [in German] LUGER, A. (1971) Hautarzt, 22, 135}

Behcet's Disease O'DUFFY, J. D., CARNEY, J. A., and DEODHAR, S. (1971) Ann. intern. Med., 75, 561

\section{Genito-urinary Tuberculosis} Gow, J. G. (1971) Practitioner, 207, 6091 fig., 4 refs
Cell-dependent Differences in the Production of Infectious Herpes Simplex Virus at a Supraoptimal Temperature $\mathrm{CROUCH}, \mathrm{N}$. A., and RAPP, F. (1972) f. Virol., 9, 223 1 fig., 22 refs

Herpes Simplex Virus Infection in the Newborn PETTAY, 0 ., LEINIKKI, P., DONNER, M., and lapinteimu, K., (1972) Arch. Dis. Childh., 47, 972 figs, 18 refs

\section{Herpes Antibody and Cervical} Carcinoma in situ CATALANO, L. W., and JOHNSON, L. D., (1971) f. Amer. med. Ass., 217, $447 \quad 10$ refs

Condylomata Acuminata (1972) Brit. med. F., 2, 179

\section{Correction}

In the paper by A. Forsgren, which appeared in the June issue of the journal (Brit. F. vener. Dis. (1972), 48, 205), in the Table on p. 205 , col. 1 , row 11 , for $36^{\circ} \mathrm{C}$, please read $56^{\circ} \mathrm{C}$. 